\title{
PELATIHAN KEBERSYUKURAN UNTUK MENURUNKAN STRES KERJA GURU DI SEKOLAH INKLUSI
}

\author{
Prapti Leguminosa ${ }^{1}$, Fuad Nashori ${ }^{2}$, Mira Aliza Rachmawati ${ }^{3}$ \\ Fakultas Psikologi dan Ilmu Sosial Budaya, Universitas Islam Indonesia \\ leguminosaakbar@ymail.com
}

Guru inklusi dituntut memiliki kompetensi yang memadai untuk bisa memberikan layanan pendidikan kepada siswa berkebutuhan khusus. Tuntutan kompetensi itu bisa memunculkan stress kerja guru di sekolah inklusi. Oleh karena itu dibutuhkan intervensi untuk mengatasi stress kerja guru inklusi, yaitu pelatihan kebersyukuran. Penelitian ini bertujuan untuk melihat pengaruh pelatihan kebersyukuran dalam menurunkan stres kerja guru di sekolah inklusi. Rancangan penelitian menggunakan untreated control group design with dependent pretest and postetst. Subjek penelitian sebanyak 14 orang terbagi ke dalam 7 orang kelompok eksperimen dan 7 orang kelompok kontrol. Analisis data menggunakan Anava Mixed Design untuk melihat perbedaan skor dalam kelompok (prates, pascates, dan tindak lanjut) serta perbedaan skor antar kelompok (eksperimen dan kontrol). Hasil analisis menunjukkan adanya perbedaan skor yang signifikan pada prates, pascates, dan tindak lanjut antar kedua kelompok $(\mathrm{F}=7,393$; dan $\mathrm{p}=0,003(\mathrm{p}<0,05))$. Hasil analisa juga menunjukkan bahwa kelompok eksperimen mengalami penurunan tingkat stres kerja setelah diberi pelatihan kebersyukuran sementara kelompok kontrol yang tidak diberi pelatihan kebersyukuran mengalami peningkatan stres kerja.

Kata kunci: Stres kerja guru, pelatihan kebersyukuran, sekolah inklusi

Teachers inclusions are required to have sufficient competence to be able to provide educational services to students with special needs. Competence demands that can bring stress of teacher in inclusive schools. Therefore, intervention is needed to overcome the stress of teacher inclusion work, namely training "kebersyukuran". This study examines the effect of gratitude training in reducing teachers work stress in inclusive schools. The study design used untreated control group design with dependent pretest and posttest. Participants of this study were 14 participants, there are 7 participants in each group. The data were analyzed using Mixed Design Anova to determine the differences of pretest, posttest, and follow-up's score, and the different between experimental and controlled group's score. The results showed a significant difference in work stress score at pretest, posttest, and follow-up between the experimental and controlled group $(F=7.393, p=0.003(p<0.05))$. In addition, there was significant changes in work stress at experimental group $(M D=13.857$ and $p=0.012)$, whereas in the control group there was no significant change $(M D=-6.571$ and $p=0.189)$. Those findings indicate that there was reduction in the level of work stress in the experimental group. Whereas the increase of work stress showed in the controlled group. Furthermore, a score partial Eta Squared $=0.561$ indicates that the gratitude training contributed $56.1 \%$ to the reduction of teacher work stress.

Keywords: teachers work stress, gratitude training, inclusive school 
Penelitian ini merupakan bagian dari penelitian payung yang mengangkat tema tentang kebersyukuran sebagai intervensi psikologis untuk guru di sekolah inklusi. Fokus dalam penelitian ini adalah pemberian intervensi berupa pelatihan kebersyukuran untuk menurunkan stres kerja guru di sekolah inklusi. Peneliti mengangkat topik tersebut karena guru di sekolah inklusi rentan mengalami stres kerja akibat banyaknya sumber stres di sekolah inklusi. Brackenreed (2011) menemukan bahwa, salah satu sumber stres kerja pada guru adalah mengajar anak berkebutuhan khusus.

Belakangan ini masyarakat semakin familiar dengan anak berkebutuhan khusus (ABK). Secara statistik, angka kelahiran anak dengan kebutuhan khusus di Indonesia belum terdata secara akurat dan spesifik. Berdasarkan Survei Antar Sensus BPS Tahun 2005, Badan Kependudukan dan Keluarga Berencana Nasional (Wimbarti, 2016) menyebutkan jumlah anak usia sekolah (5-14 tahun) sebesar 42.870.041 jiwa. Dari jumlah tersebut diperkirakan ada kurang lebih 4,2 juta anak dengan kebutuhan khusus jika mengacu asumsi PBB (Persatuan Bangsa-Bangsa) yang memperkirakan bahwa paling sedikit 10\% anak usia sekolah menyandang kebutuhan khusus. Jumlah anak berkebutuhan khusus yang cukup banyak juga cukup menyita perhatian pemerintah. Hal ini tampak dari layanan pendidikan khusus yang disediakan bagi anak berkebutuhan khusus salah satunya adalah pendidikan inklusi. Pendidikan inklusi merupakan salah satu layanan pendidikan dimana anak-anak berkebutuhan khusus mengenyam pendidikan di sekolah-sekolah reguler bersama anak normal lainnya (Puspitasari \& Handyani, 2014). Pendidikan inklusi menjadi sorotan penting di Daerah Istimewa Yogyakarta karena ditetapkan sebagai pusat pengembangan pendidikan inklusi di wilayah ASEAN. Oleh sebab itu, pendidikan inklusi perlu menjadi perhatian di Daerah Istimewa Yogyakarta.

Pendidikan inklusi dan anak berkebutuhan khusus memang telah mendapat perhatian, namun penelitian dan intervensi di lingkungan psikologi belum banyak dilakukan. Kalaupun ada, fokusnya hanya pada siswa atau pada peningkatan kompetensi guru di sekolah inklusi saja. Di Indonesia, masih jarang ditemukan literatur atau penelitian tentang intervensi psikologis untuk meningkatkan kesejahteraan psikologis guru di sekolah inklusi. Padahal, guru inklusi memiliki potensi yang besar mengalami stres kerja, terlebih mereka dituntut untuk memberikan layanan pendidikan bagi anak normal dan anak berkebutuhan khusus dalam satu waktu.

Peneliti telah mewawancari beberapa guru sekolah inklusi di kota Yogyakarta. Dari hasil wawancara diketahui bahwa guru-guru di sekolah inklusi memiliki lebih banyak tugas serta tuntutan dibandingkan guru di sekolah reguler. Karakteristik siswa yang berbedabeda membuat para guru dihadapkan oleh berbagai macam kendala dalam bekerja. Beberapa upaya yang telah dilakukan sekolah yakni dengan menghadirkan guru pendamping khusus (GPK) untuk membantu guru kelada dalam membimbing siswa berkebutuhan khusus. Terdapat dua hingga empat orang guru di dalam kelas yang disesuaikan dengan jumlah dan kebutuhan siswa. Upaya lainnya yakni peningkatan kompetensi guru sebagai pengajar di sekolah inklusi melalui diklat dan kegiatan rutin yang disebut dengan kelompok kerja guru (KKG). Kedua kegiatan tersebut bertujuan untuk meningkatkan kemampuan guru dalam bidang pengetahuan umum, administrasi pembelajaran, manajemen kelas, serta merancang dan menyusun media belajar.

Meskipun para guru telah memperoleh kompetensi yang memadai, tidak dapat dipungkiri bahwa mereka tetap mengalami stres kerja. Guru-guru di sekolah inklusi mengeluh merasa sangat lelah baik secara fisik maupun emosi setiap harinya karena menghadapi 
siswa dengan kebutuhan yang beragam dalam satu waktu. Para guru juga merasa frustrasi karena progres belajar siswa yang sangat lambat, tidak sesuai dengan harapan mereka, serta karena banyaknya tugas administrasi sehingga mereka merasa tidak memiliki waktu yang cukup untuk menyelesaikannya. Di samping itu, para guru memperoleh gaji yang sangat minim (tidak mencapai UMR). Berbagai hal tersebut menyebabkan para guru kerap merasakan emosi-emosi negatif (marah, bosan, kecewa, tertekan) dan mempengaruhi kondisi fisik mereka (merasa cepat lelah, detak jantung dan tekanan darah meningkat, asam lambung meningkat). Dengan demikian dapat diketahui bahwa, berbagai keluhan para guru di atas muncul karena ketidakmampuan mereka mengelola berbagai sumber stres dalam pekerjaan mereka.

Antoniou dkk (2009) mengklasifikasikan tiga sumber stres guru, yakni: (1) Administratif (beban kerja yang berat, peran kerja yang berlebihan, konflik dalam peran kerja, peran kerja yang tidak jelas, hambatan-hambatan dalam waktu atau sumber daya); (2) Ruang kelas (suasana ruang kelas, rasio siswa dan guru yang tidak sesuai, progress siswa yang sangat terbatas dengan perilaku yang mengganggu); (3) Personal (kolaborasi yang kurang dengan kolega/antar pengajar, lingkungan kerja yang tidak baik, gaji yang tidak layak dan status sosial yang rendah).

Perasaan lelah secara emosional terhadap sumber stres yang dirasakan oleh guru merupakan wujud dari stres kerja. Para peneliti mendefinisikan stres sebagai sebuah respon fisik, mental, atau emosi terhadap kejadian-kejadian yang menyebabkan tekanan pada tubuh atau mental (Brackenreed, 2011). Sementara, penggunaan terminologi stres kerja tergantung pada hal-hal tertentu yang menyebabkan stres dan perwujudan dari stres itu sendiri (fisik, perilaku, dan gejala-gejala lainnya) (Fimian, 1988). Bagi guru, stres didefinisikan sebagai sebuah respon terhadap efek negatif dari pekerjaan sebagai guru (Brackenreed, 2011).

Lewis (2006) menyebutkan bahwa bekerja sebagai guru termasuk dalam lima besar pekerjaan yang paling membuat stres di dunia. Stres kerja yang dirasakan guru terjadi karena tidak adanya pengelolaan stres yang baik sehingga burnout yang berpengaruh negatif pada performa kerja dan kesehatan (Maslach dkk, 2001). Menurut Kelso dkk (2005) stres kerja yang berkepanjangan akan menyebabkan gangguan kesehatan pada fisik, mental, dan emosi serta dapat merusak kualitas mengajar. Stres kerja yang tinggi juga berhubungan dengan ketidakpuasan kerja, ketidak hadiran, dan tingginya turn over kerja (Billingsley \& Cross 1992).

Dari berbagai pemaparan di atas dapat diketahui bahwa di sekolah inklusi terdapat berbagai sumber stres atau pemicu stres yang jika tidak dapat dikelola dengan baik oleh guru, maka akan menjadi stres kerja. Stres kerja yang dirasakan guru akan mempengaruhi kualitas atau performa kerja mereka. Oleh sebab itu, guru perlu memiliki strategi untuk mengelola stres. Salah satu cara yang digunakan untuk mengatasi stres kerja, yakni melalui intervensi bersyukur (Cahyono, 2014). Melatih kebersyukuran pada karyawan terbukti efektif menurunkan stres kerja mereka (Cahyono, 2014). Emmons \& Stern (2013) dalam penelitiannya juga menemukan bahwa orang yang bersyukur lebih efektif dalam mengatasi stres sehari-hari, memiliki resilien yang tinggi dalam menghadapi stres, lebih cepat sembuh dari penyakit, serta lebih menikmati kesahatan fisik. Emmons \& Crumpler (2000) menemukan bahwa, individu yang memiliki rasa syukur tinggi 
cenderung mampu mengatasi stres dengan lebih baik dan memperlihatkan fungsi fisik dan psikologis yang lebih positif setelah mengalami trauma.

Merasa bersyukur memiliki banyak dampak positif baik dari segi emosional, fisik, dan interpersonal (Emmons \& McCullough, 2003). Orang yang memiliki rasa syukur tinggi cenderung memiliki tingkat emosi positif yang tinggi dan tingkat emosi negatif yang rendah seperti kecemasan, iri (McCullough dkk, 2002), tingkat stress dan depresi yang rendah (McCullough dkk, 2004). Dalam lingkungan kerja, perasaan bersyukur membawa dampak positif baik bagi individu itu sendiri maupun organisasi. Emosi positif yang dirasakan individu tersebut yang akan mendorong peningkatan performa individu dalam organisasi.

Mempertimbangkan berbagai hasil penelitian terdahulu tentang dampak positiif dari meningkatkan rasa syukur yang salah satunya yakni dapat menurunkan stres kerja, maka dalam penelitian ini akan melakukan intervensi berupa pelatihan kebersyukuran untuk menurunkan stres kerja pada guru di sekolah inklusi.

\section{METODE}

\section{Rancangan Penelitian}

Peneliti menggunakan desain untreated control group design with dependent prates and postetst. Shadish dkk (2002) mengemukakan bahwa desain untreated control group design with dependent pretest and postetst yaitu desain eksperimen yang dirancang dengan membagi subjek ke dalam kelompok eksperimen dan kelompok kontrol.

\section{Gambar 1. Rancangan Penelitian}

\begin{tabular}{lcccc}
\hline Kelompok & Prates & Treatment & Pascates & $\begin{array}{c}\text { Tindak } \\
\text { lanjut }\end{array}$ \\
\hline $\begin{array}{l}\text { Kelompok Eksperimen } \\
\text { Control Group }\end{array}$ & $\mathrm{O1}$ & $\mathrm{X}$ & $\mathrm{O2}$ & $\mathrm{O3}$ \\
& $\mathrm{O1}$ & & $\mathrm{O2}$ & $\mathrm{O3}$ \\
\hline
\end{tabular}

\begin{tabular}{lll}
\hline Keterangan: & & \\
$\mathrm{O} 1 \quad=$ Prates & $\mathrm{X}$ & $=$ Treatment \\
$\mathrm{O} 2$ & $=$ Postets & $\mathrm{O} 3 \quad=$ Tindak lanjut
\end{tabular}

\section{Subjek Penelitian}

Responden penelitian ini adalah guru-guru dari dua sekolah inklusi Daerah Istimewa Yogyakarta. Responden dalam penelitian adalah 14 orang (laki-laki dan perempuan) yang memiliki skor stres kerja tinggi dan sedang berdasarkan hasil pengukuran menggunakan skala stres kerja guru. 14 orang pasrtisipan dibagi ke dalam dua kelompok yaitu, 7 orang dalam kelompok eksperimen dan 7 orang dalam kelompok kontrol. Responden direkrut dengan bantuan kepala sekolah melalui rapat internal guru dan atas perasaan suka rela dari guru sendiri. 


\section{Variabel dan Instrumen Penelitian}

Variabel terikat dalam penelitian ini adalah stres kerja guru dan variabel bebas adalah pelatihan kebersyukuran. Metode pengumpulan data menggunakan Teacher Stress Inventory (TSI) dari Fimian (1988) yang dimodifikasi oleh peneliti. Terdapat dua hal yang diukur untuk mengetahui tingkat stres kerja guru, yaitu kejadian-kejadian yang menjadi sumber stres kerja dan manifestasi dari stres kerja. Teacher Stress Inventory (TSI) digunakan untuk melihat keadaan subjek sebelum dilakukan perlakuan dan setelah dilakukan perlakuan yakni pelatihan kebersyukuran.

\section{Prosedur dan Analisis Data}

Prosedur penelitian terdiri dari tiga tahap yaitu persiapan, pelaksanaan, dan analisis. Tahap persiapan diawali dengan pemilihan subjek sesuai dengan kriteria, subjek diberikan alat ukur Teacher Stress Inventory (TSI) untuk melihat keadaan awal stress kerja dari guru sekolah inklusi, kegiatan ini disebut sebagai pretest. Tahap kedua yaitu pelaksanaan intervensi dimana subjek dibagi dalam kelompok eksperimen dan kelompok kontrol, kelompok eksperimen akan mendapat perlakuan berupa terapi kebersyukuran untuk menurunkan stress kerja guru sekolah inklusi. Modul pelatihan terapi kebersyukuran disusun berdasarkan tiga aspek kebersyukuran, yakni bersyukur dengan hati, bersyukur dengan lisan, dan bersyukur dengan perilaku (Al-Jauziyyah, 2010; AlMunajjid, 2006). Tujuannya adalah membantu guru di sekolah inklusi mengoptimalisasikan energi syukurnya sehingga mampu mengatasi stres kerja. Diakhiri dengan melakukan posttest menggunakan Teacher Stress Inventory (TSI). Tahap ketiga yaitu analisa data untuk melihat perubahan keadaan stress kerja guru inklusi dan perbedaan stress kerja pada kelompok eksperimen dan kelompok kontrol. Uji hipotesis yang digunakan dalam penelitian ini adalah Anava Mixed Design, dimana analisis ini memadukan dua sub analisis yaitu Within Subject Test dan Between Subject Test.Within Subject Test adalah pengujian perbedaan skor dalam satu kelompok (prates, pasca tes, tindak lanjut), sedangkan Between Subject Test adalah pengujian perbedaan skor antar kelompok (eksperimen dan kontrol) (Widhiarso, 2010).

\section{HASIL}

Hipotesis dalam penelitian ini adalah stres kerja kelompok yang diberikan perlakuan pelatihan kebersyukuran lebih rendah daripada kelompok yang tidak diberi perlakuan pelatihan kebersyukuran. Analisis data yang digunakan untuk menguji hipotesa dalam penelitian ini dilakukan dengan menggunakan uji statistik mixed anova dengan melihat tabel test of within - subject effect. Adapun hasil uji hipotesa ada pada Tabel 1.

Tabel 1. Hasil Uji Interaksi

\begin{tabular}{|c|c|c|c|c|c|c|c|}
\hline & Source & $\begin{array}{c}\text { Type III } \\
\text { Sum of } \\
\text { Squares }\end{array}$ & df & $\begin{array}{l}\text { Mean } \\
\text { Square }\end{array}$ & $\mathbf{F}$ & Sig. & $\begin{array}{c}\text { Partial Eta } \\
\text { Squared }\end{array}$ \\
\hline \multirow[t]{4}{*}{$\begin{array}{l}\text { time } \\
\text { Kelompok }\end{array}$} & $\begin{array}{l}* \text { Sphericity } \\
\text { Assumed }\end{array}$ & 1062.333 & 2 & 531.167 & 7.397 & .003 & .381 \\
\hline & $\begin{array}{l}\text { Greenhouse- } \\
\text { Geisser }\end{array}$ & 1062.333 & 1.710 & 621.238 & 7.397 & .005 & .381 \\
\hline & Huynh-Feldt & 1062.333 & 2.000 & 531.167 & 7.397 & .003 & .381 \\
\hline & Lower-bound & 1062.333 & 1.000 & 1062.333 & 7.397 & .019 & .381 \\
\hline
\end{tabular}


Pada Tabel 1 dapat dilihat pada baris time*kelompok dan sub baris Sphericity Assumed, diketahui nilai $\mathrm{F}=7,393$ dan nilai $\mathrm{p}=0,003(\mathrm{p}<0,05)$. Artinya, terdapat interaksi antara waktu pengukuran (prates, pascates, dan tindak lanjut) dan kelompok (eksperimen dan kontrol). Interaksi tersebut menunjukkan bahwa perubahan skor prates, pascates, hingga tindak lanjut pada kedua kelompok (eksperimen dan kontrol) adalah berbeda secara signifikan. Setelah diketahui bahwa terjadi interaksi yang signifikan antara time (prates, pascates, tindak lanjut) dan kelompok (eksperimen-kontrol), maka langkah selanjutnya adalah melihat efektivitas intervensi. Efektivitas intervensi Pairwise Comparison dapat dilihat pada Tabel 2.

Tabel 2. Hasil Uji Pairwise Comparison

\begin{tabular}{|c|c|c|c|c|c|c|c|}
\hline \multirow[t]{2}{*}{ Kelompok } & \multirow[t]{2}{*}{ (I) time } & \multirow[t]{2}{*}{ (J) time } & \multirow{2}{*}{$\begin{array}{c}\text { Mean } \\
\text { Difference } \\
\text { (I-J) }\end{array}$} & \multirow[t]{2}{*}{ Std. Error } & \multirow[t]{2}{*}{ Sig. ${ }^{a}$} & \multicolumn{2}{|c|}{$\begin{array}{l}\text { 95\% Confidence Interval for } \\
\text { Difference }^{\mathrm{a}}\end{array}$} \\
\hline & & & & & & Lower Bound & Upper Bound \\
\hline \multirow[t]{6}{*}{ Eksperimen } & & 2 & $13.857^{*}$ & 4.716 & .012 & 3.581 & 24.133 \\
\hline & & 3 & $20.286^{*}$ & 5.178 & .002 & 9.004 & 31.568 \\
\hline & 2 & 1 & $-13.857^{*}$ & 4.716 & .012 & -24.133 & -3.581 \\
\hline & & 3 & 6.429 & 3.534 & .094 & -1.272 & 14.129 \\
\hline & 3 & 1 & $-20.286^{*}$ & 5.178 & .002 & -31.568 & -9.004 \\
\hline & & 2 & -6.429 & 3.534 & .094 & -14.129 & 1.272 \\
\hline \multirow[t]{6}{*}{ Kontrol } & 1 & 2 & -6.571 & 4.716 & .189 & -16.848 & 3.705 \\
\hline & & 3 & -1.857 & 5.178 & .726 & -13.139 & 9.425 \\
\hline & 2 & 1 & 6.571 & 4.716 & .189 & -3.705 & 16.848 \\
\hline & & 3 & 4.714 & 3.534 & .207 & -2.986 & 12.414 \\
\hline & 3 & 1 & 1.857 & 5.178 & .726 & -9.425 & 13.139 \\
\hline & & 2 & -4.714 & 3.534 & .207 & -12.414 & 2.986 \\
\hline
\end{tabular}

Hasil uji pairwise comparisons di atas menunjukkan bahwa penurunan stres kerja guru pada kelompok eksperimen adalah signifikan $(\mathrm{MD}=13,857$ dan $\mathrm{p}=0,012$ ) dimana $\mathrm{p}<0,05$. Nilai MD positif menunjukkan bahwa rerata pascates lebih rendah daripada rerata prates, artinya responden pada kelompok eksperimen mengalami penurunan stres kerja. Sedangkan pada kelompok kontrol diperoleh hasil MD $=-6,571$ dan $p=0,189$ (tidak signifikan) karena $\mathrm{p}>0.05$. Nilai MD negatif menunjukkan bahwa rerata pascates lebih tinggi daripada rerata prates. Artinya responden pada kelompok kontrol justru mengalami peningkatan stres kerja pada pengukuran pascates.

Rerata tindak lanjut pada kelompok eksperimen lebih rendah dari pada rerata pascates $(\mathrm{MD}=6,429$ dan $\mathrm{p}=0,094)$. Nilai MD positif menunjukkan terjadinya penurunan stres kerja kelompok eksperimen dari pascates menuju tindak lanjut. Namun demikian, penurunan tersebut tidak signifikan dimana nilai $p>0,05$. Sementara pada kelompok kontrol diperoleh hasil rerata tindak lanjut lebih rendah dibandingkan rerata pascates $(\mathrm{MD}=4,714$ dan $\mathrm{p}=0,207)$. Artinya adalah, responden pada kelompok kontrol mengalami penurunan stres kerja pada pengukuran tindak lanjut, namun demikian penurunan stres kerja tersebut juga tidak signifikan dimana $\mathrm{p}>0,05$. 
Berdasarkan pemaparan hasil uji pairwise comparisons dapat diketahui bahwa pelatihan kebersyukuran dapat menurunkan stres kerja guru sekolah inklusi. Penurunan stres kerja tetap berlangsung hingga lebih dari dua minggu setelah intervensi (pelatihan kebersyukuran diberikan).

Selanjutnya sumbangan efektif intervensi pelatihan kebersyukuran terhadap penurunan stres kerja guru sekolah inklusi dapat dilihat melalui hasil analisis statistik Multivariate Test pada Tabel 3.

Tabel 3. Hasil Uji Multivariate

\begin{tabular}{lccccccc}
\hline Kelompok & & Value & F & $\begin{array}{c}\text { Hypothesis } \\
\text { df }\end{array}$ & Error df & Sig. & $\begin{array}{c}\text { Partial Eta } \\
\text { Squared }\end{array}$ \\
\hline Eksperimen & Wilks' lambda & .439 & $7.034^{\mathrm{a}}$ & 2.000 & 11.000 & .011 & .561 \\
Kontrol & Wilks' lambda & .800 & $1.378^{\mathrm{a}}$ & 2.000 & 11.000 & .292 & .200 \\
\hline
\end{tabular}

Pada Tabel 3 dapat dilihat pada baris eksperimen Wilks' lambda diketahui nilai Partial Eta Squared $=0,561$. Hal tersebut menunjukkan bahwa pelatihan kebersyukuran memberikan kontribusi sebesar 56,1\% terhadap penurunan stress kerja guru sekolah inklusi. Selanjutnya adalah melakukan analisis pada masing-masing aspek skala stres kerja guru yakni, aspek sumber stres dan aspek manifestasi stres.

\section{1) Hasil Analisis Aspek Sumber Stres}

Tabel 4. Hasil Uji Interaksi Aspek Stres Kerja (Sumber Stres)

\begin{tabular}{llcccccc}
\hline & Source & $\begin{array}{l}\text { Type III } \\
\text { Sum of } \\
\text { Squares }\end{array}$ & df & $\begin{array}{c}\text { Mean } \\
\text { Square }\end{array}$ & F & Sig. & $\begin{array}{c}\text { Partial Eta } \\
\text { Squared }\end{array}$ \\
\hline time & * Sphericity & 394.905 & 2 & 197.452 & 8.226 & .002 & .407 \\
& $\begin{array}{l}\text { Assumed } \\
\text { Kelompok }\end{array}$ & & & & & & .407 \\
& $\begin{array}{l}\text { Greenhouse- } \\
\text { Geisser }\end{array}$ & 394.905 & 1.625 & 243.007 & 8.226 & .004 & .407 \\
& Huynh-Feldt & 394.905 & 2.000 & 197.452 & 8.226 & .002 & .407 \\
& Lower-bound & 394.905 & 1.000 & 394.905 & 8.226 & .014 & .407 \\
\hline
\end{tabular}

Pada tabel 4 di atas dapat dilihat pada baris time*kelompok dan sub baris Sphericity Assumed, diketahui nilai $\mathrm{F}=8,226$ dan nilai $\mathrm{p}=0,002$. Hal ini berarti terdapat interaksi antara waktu pengukuran (prates, pascates, dan tindak lanjut) dan kelompok (eksperimen dan kontrol). Interaksi tersebut menunjukkan bahwa perubahan skor aspek sumber stres pada prates, pascates, hingga tindak lanjut pada kedua kelompok (eksperimen dan kontrol) adalah berbeda secara signifikan $(\mathrm{p}<0,05)$.

Setelah diketahui bahwa terjadi interaksi yang signifikan antara time (prates, pascates, tindak lanjut) dan kelompok (eksperimen-kontrol), maka langkah selanjutnya adalah melihat efektivitas intervensi terhadap aspek sumber stres. Efektivitas intervensi Pairwise Comparison dapat dilihat pada Tabel 5. 
Tabel 5. Hasil Uji Pairwise Comparison Aspek Stres Kerja (Sumber Stres)

\begin{tabular}{lccrrrrr}
\hline \multirow{2}{*}{ Kelompok } & $\begin{array}{c}\text { (I) } \\
\text { time }\end{array}$ & $\begin{array}{c}\text { (J) } \\
\text { time }\end{array}$ & $\begin{array}{c}\text { Mean } \\
\text { Difference } \\
(\mathrm{I}-\mathrm{J})\end{array}$ & $\begin{array}{c}\text { Std. } \\
\text { Error }\end{array}$ & Sig. $^{\text {a }}$ & \multicolumn{2}{c}{$\begin{array}{c}\text { 95\% Confidence Interval for } \\
\text { Difference }\end{array}$} \\
\hline Eksperimen & 1 & 2 & $7.143^{*}$ & 2.645 & .019 & 1.380 & 12.906 \\
& & 3 & $10.857^{*}$ & 3.105 & .004 & 4.092 & 17.622 \\
& 2 & 1 & $-7.143^{*}$ & 2.645 & .019 & -12.906 & -1.380 \\
& & 3 & 3.714 & 1.985 & .086 & -.610 & 8.038 \\
& 3 & 1 & $-10.857^{*}$ & 3.105 & .004 & -17.622 & -4.092 \\
& & 2 & -3.714 & 1.985 & .086 & -8.038 & .610 \\
\hline Kontrol & 1 & 2 & $-6.143^{*}$ & 2.645 & .039 & -11.906 & -.380 \\
& & 3 & -1.857 & 3.105 & .561 & -8.622 & 4.908 \\
& 2 & 1 & $6.143^{*}$ & 2.645 & .039 & .380 & 11.906 \\
& & 3 & 4.286 & 1.985 & .052 & -.038 & 8.610 \\
& 3 & 1 & 1.857 & 3.105 & .561 & -4.908 & 8.622 \\
& & 2 & -4.286 & 1.985 & .052 & -8.610 & .038 \\
\hline
\end{tabular}

Dari Tabel 5 di atas dapat dilihat $M D=7,143$ dan $p=0,019$. Nilai positif pada MD menunjukkan bahwa rerata pada pascates lebih rendah daripada rerata prates. Artinya, responden pada kelompok eksperimen mengalami penurunan stres dalam aspek sumber stres dan penurunan tersebut signifikan $(\mathrm{p}<0,05)$. Sementara itu, pada kelompok yang tidak diberikan intervensi atau kelompok kontrol diperoleh $\mathrm{MD}=-6,143$ dan $\mathrm{p}=0,039$. Nilai minus pada MD menunjukkan bahwa rerata pada pascates lebih tinggi daripada rerata prates. Artinya pada saat pascates kelompok kontrol mengalami peningkatan stres kerja dalam aspek sumber stres dan peningkatan tersebut signifikan $(\mathrm{p}<0,05)$.

Sementara itu, pada saat tindak lanjut rerata aspek sumber stres pada kelompok eksperimen $(\mathrm{MD}=3,741$ dan $\mathrm{p}=0,086)$ juga mengalami penurunan dibandingkan saat pascates. Artinya, hingga tahap tindak lanjut (15 hari setelah intervensi) tetap terjadi penurunan stres kerja dalam aspek sumber stres meskipun penurunan tersebut tidak signifikan $(\mathrm{p}>0,05)$. Sedangkan pada kelompok kontrol rerata aspek sumber stres kerja pada saat tindak lanjut yakni $\mathrm{M}=4,286$ dan $\mathrm{p}=0,052$. Artinya jika dibandingkan antara saat pascates dengan tindak lanjut terjadi penurunan stres kerja dalam aspek sumber stres pada kelompok kontrol.

Selanjutnya sumbangan efektif intervensi pelatihan kebersyukuran terhadap penurunan stres kerja khususnya aspek sumber stres dapat dilihat pada hasil analisis statistik Multivariate Test pada Tabel 6

Tabel 6. Hasil Uji Multivariate Aspek Stres Kerja (Sumber Stres)

\begin{tabular}{llcccccc}
\hline Kelompok & & Value & F & Hypothesis df & Error df & Sig. & $\begin{array}{c}\text { Partial Eta } \\
\text { Squared }\end{array}$ \\
\hline Eksperimen & Wilks' lambda & .495 & $5.605^{\mathrm{a}}$ & 2.000 & 11.000 & .021 & .505 \\
\hline Kontrol & Wilks' lambda & .573 & $4.104^{\mathrm{a}}$ & 2.000 & 11.000 & .047 & .427 \\
\hline
\end{tabular}


Pada baris eksperimen Wilks' lambda tabel 6 diketahui nilai Partial Eta Squared = 0,505. Hal tersebut menunjukkan bahwa pelatihan kebersyukuran memberikan kontribusi sebesar 50,5\% terhadap penurunan stres kerja dalam aspek sumber stres.

\section{2) Hasil Analisis Aspek Sumber Stres}

Tabel 7. Hasil Uji Interaksi Aspek Stres Kerja (Manifestasi Stres)

\begin{tabular}{llccccccc}
\hline & Source & $\begin{array}{c}\text { Type III Sum of } \\
\text { Squares }\end{array}$ & df & $\begin{array}{c}\text { Mean } \\
\text { Square }\end{array}$ & F & Sig. & $\begin{array}{c}\text { Partial } \\
\text { Eta } \\
\text { Squar } \\
\text { ed }\end{array}$ \\
\hline $\begin{array}{l}\text { time } \\
\text { Kelompok }\end{array}$ & $\begin{array}{l}* \text { Sphericity } \\
\text { Assumed } \\
\text { Greenhouse- }\end{array}$ & 169.333 & 2 & 84.667 & 3.815 & .036 & .241 \\
& $\begin{array}{l}\text { Geisser } \\
\text { Huynh-Feldt }\end{array}$ & 169.333 & 1.811 & 93.490 & 3.815 & .042 & .241 \\
& 169.333 & 2.000 & 84.667 & 3.815 & .036 & .241 \\
& Lower-bound & 169.333 & 1.000 & 169.333 & 3.815 & .075 & .241 \\
\hline
\end{tabular}

Pada Tabel 7 di atas dapat dilihat pada baris time*kelompok dan sub baris Sphericity Assumed, diketahui nilai $\mathrm{F}=3,815$ dan nilai $\mathrm{p}=0,036$. Hal ini berarti terdapat interaksi antara waktu pengukuran (prates, pascates, dan tindak lanjut) dan kelompok (eksperimen dan kontrol). Interaksi tersebut menunjukkan bahwa perubahan skor aspek manifestasi stres pada prates, pascates, hingga tindak lanjut pada kedua kelompok (eksperimen dan kontrol) adalah berbeda secara signifikan $(\mathrm{p}<0,05)$.

Setelah mengetahui terjadi interaksi yang signifikan antara waktu (prates, pascates, tindak lanjut) dan kelompok (eksperimen-kontrol), maka langkah selanjutnya adalah melihat efektivitas intervensi terhadap aspek manifestasi stres. Efektivitas intervensi dapat dilihat pada Tabel 8

Tabel 8. Uji Pairwise Comparison Aspek Stres Kerja (Manifestasi Stres)

\begin{tabular}{|c|c|c|c|c|c|c|c|}
\hline \multirow[t]{2}{*}{ Kelompok } & \multirow{2}{*}{$\begin{array}{l}\text { (I) } \\
\text { time }\end{array}$} & \multirow{2}{*}{$\begin{array}{l}(\mathrm{J}) \\
\text { time }\end{array}$} & \multirow{2}{*}{$\begin{array}{l}\text { Mean } \\
\text { Difference (I-J) }\end{array}$} & \multirow{2}{*}{ Std. Error Sig. } & \multicolumn{3}{|c|}{$\begin{array}{l}\text { 95\% Confidence Interval for } \\
\text { Difference }^{\mathrm{a}}\end{array}$} \\
\hline & & & & & & Lower Bound & Upper Bound \\
\hline \multirow[t]{6}{*}{ Eksperimen } & 1 & 2 & $6.714^{*}$ & 2.827 & .035 & .556 & 12.873 \\
\hline & & 3 & $9.429^{*}$ & 2.563 & .003 & 3.845 & 15.012 \\
\hline & 2 & 1 & $-6.714^{*}$ & 2.827 & .035 & -12.873 & -.556 \\
\hline & & 3 & 2.714 & 2.113 & .223 & -1.890 & 7.319 \\
\hline & 3 & 1 & $-9.429^{*}$ & 2.563 & .003 & -15.012 & -3.845 \\
\hline & & 2 & -2.714 & 2.113 & .223 & -7.319 & 1.890 \\
\hline \multirow[t]{6}{*}{ Kontrol } & 1 & 2 & -.429 & 2.827 & .882 & -6.587 & 5.730 \\
\hline & & 3 & .000 & 2.563 & 1.000 & -5.584 & 5.584 \\
\hline & 2 & 1 & .429 & 2.827 & .882 & -5.730 & 6.587 \\
\hline & & 3 & .429 & 2.113 & .843 & -4.176 & 5.033 \\
\hline & 3 & 1 & .000 & 2.563 & 1.000 & -5.584 & 5.584 \\
\hline & & 2 & -.429 & 2.113 & .843 & -5.033 & 4.176 \\
\hline
\end{tabular}


Dari Tabel 8 di atas dapat dilihat $M D=6,714$ dan $p=0,035$. Nilai positif pada MD menunjukkan bahwa rerata pada pascates lebih rendah daripada rerata prates. Artinya, responden pada kelompok eksperimen mengalami penurunan stres dalam aspek manifestasi stres dan penurunan tersebut signifikan $(p<0,05)$. Sementara itu, pada kelompok kontrol diperoleh $\mathrm{MD}=-0,429$ dan $\mathrm{p}=0,882$. Nilai minus pada $\mathrm{MD}$ menunjukkan bahwa rerata pada pascates lebih tinggi daripada rerata prates. Artinya pada saat pascates kelompok yang tidak diberi perlakuan mengalami peningkatan stres kerja dalam aspek manifestasi stres meskipun peningkatan tersebut tidak signifikan ( $p>0,05)$.

Sementara itu, pada saat tindak lanjut rerata aspek manifestasi stres pada kelompok eksperimen $(\mathrm{MD}=2,714$ dan $\mathrm{p}=0,228)$ juga mengalami penurunan dibandingkan saat pascates. Artinya, hingga tahap tindak lanjut (15 hari setelah intervensi) tetap terjadi penurunan stres kerja dalam aspek manifestasi stres meskipun penurunan tersebut tidak signifikan $(p>0,05)$. Sedangkan pada kelompok kontrol rerata aspek sumber stres kerja pada saat tindak lanjut yakni $M=0,429$ dan $p=0,843$. Artinya jika dibandingkan antara saat pascates dengan tindak lanjut terjadi penurunan stres kerja dalam aspek manifestasi stres namun penurunan tersebut tidak signifikan $(p>0,05)$.

Selanjutnya sumbangan efektif intervensi pelatihan kebersyukuran terhadap penurunan stres kerja guru dalam aspek manifestasi stres dapat dilihat melalui hasil analisis statistik Multivariate Test pada Tabel 9.

Tabel 9. Hasil Uji Multivariate Aspek Stres Kerja (Manifestasi Stres)

\begin{tabular}{llcccccc}
\hline Kelompok & & Value & $\mathrm{F}$ & Hypothesis df & Error df & Sig. & Partial Eta Squared \\
\hline Eksperimen & $\begin{array}{l}\text { Wilks' } \\
\text { lambda }\end{array}$ & .469 & $6.235^{\mathrm{a}}$ & 2.000 & 11.000 & .015 & .531 \\
Kontrol & $\begin{array}{l}\text { Wilks' } \\
\text { lambda }\end{array}$ & .996 & $.020^{\mathrm{a}}$ & 2.000 & 11.000 & .980 & .004
\end{tabular}

Pada baris eksperimen Wilks' lambda tabel 9 diketahui nilai Partial Eta Squared =0,531. Hal tersebut menunjukkan bahwa pelatihan kebersyukuran memberikan kontribusi sebesar 53,1\% terhadap penurunan stres kerja dalam aspek Manifestasi stres.

\section{DISKUSI}

Penelitian ini bertujuan untuk menurunkan stres kerja guru di sekolah inklusi melalui pelatihan kebersyukuran. Pada setiap tempat kerja termasuk sekolah pasti terdapat berbagai macam sumber stres. Beberapa sumber stres di SD X diantaranya adalah beban kerja yang berat, hambatan-hambatan dalam waktu atau sumber daya, progres siswa yang sangat terbatas dengan perilaku yang mengganggu, gaji yang tidak layak dan status sosial yang rendah. Berbagai sumber stres tersebut jika tidak dapat dikelola dengan baik akan memunculkan perasaan lelah secara emosional, kondisi fisik yang lemah, dan performa kerja yang tidak optimal (manifestasi stres). Kelso dkk (2005) menemukan bahwa stres kerja yang berkepanjangan akan menyebabkan gangguan kesehatan pada fisik, mental, dan emosi serta dapat merusak kualitas mengajar. 
Pada penelitian ini tingkat stres kerja guru diukur menggunakan skala stres kerja. Pengukuran dilakukan tiga kali yakni pada tahap prates, pascates, dan tindak lanjut. Berdasarkan hasil analisis data dapat diketahui bahwa skor rerata pascates kelompok yang diberikan intervensi pelatihan kebersyukuran (kelompok eksperimen) mengalami penurunan jika dibandingkan dengan skor rerata prates. Sementara kelompok yang tidak diberikan intervensi pelatihan kebersyukuran (kelompok kontrol) menunjukkan adanya peningkatan skor rerata pascates dibandingkan skor rerata prates. Hal ini berarti bahwa hipotesis dalam penelitian ini dapat diterima. Stres kerja kelompok yang diberikan intervensi pelatihan kebersyukuran lebih rendah daripada kelompok yang tidak diberi intervensi pelatihan kebersyukuran.

Hasil penelitian ini telah mencapai tujuan penelitian dan membuktikan bahwa pelatihan kebersyukuran telah berperan dalam upaya menurunkan stres kerja guru inklusi (SD "X"). Sejalan dengan pendapat Emmons \& Stern (2013) yang menyatakan bahwa orang yang bersyukur akan lebih efektif dalam mengatasi stres sehari-hari dan memiliki resilien yang tinggi dalam menghadapi stres. Fitch-Martin (2015) juga menemukan adanya hubungan antara kebersyukuran dengan tingkat stres mahasiswa. Penelitian Cahyono (2014) juga membuktikan bahwa pelatihan kebersyukuran efektif menurunkan stres kerja karyawan.

Selain melakukan analisis data prates dan pascates peneliti juga menganalisis data pascates dan tindak lanjut. Hasilnya adalah pada kelompok eksperimen rerata stres kerja saat tindak lanjut lebih rendah dibandingkan rerata pascates. Hal ini berarti bahwa tingkat stres kerja guru (kelompok eksperimen) tetap menurun bahkan hingga kurang lebih dua minggu pasca intervensi. Selain itu, peneliti juga melakukan analisis data per aspek. Fimian (1988) menyatakan bahwa terdapat dua hal yang diukur untuk mengidentifikasi stres kerja, yaitu kejadian-kejadian yang menjadi sumber stres kerja (yang disebut sebagai aspek sumber stres) dan kejadian-kejadian yang merupakan manifestasi dari stres kerja (yang disebut sebagai aspek manifestasi stres). Hasilnya menunjukkan bahwa pelatihan kebersyukuran memberikan kontribusi yang sepadan pada kedua aspek tersebut. Pelatihan kebersyukuran memberikan konribusi sebesar 50,5\% terhadap penurunan stres kerja dalam aspek sumber stres dan 53,1\% terhadap penurunan stres kerja dalam aspek manifestasi stres. Dari hasil analisis data tersebut membuktikan bahwa pelatihan kebersyukuran dapat dikatakan cukup efektif untuk menurunkan stres kerja guru di "SD X”.

Hasil analisis kualitatif juga menunjukkan bahwa pelatihan kebersyukuran dapat menurunkan stres kerja guru di sekolah inklusi. Guru-guru "SD X" merasakan adanya perubahan positif setelah mengaplikasikan keterampilan syukur hati, lisan, dan perilaku. Dengan bersyukur para guru terdorong untuk berpikir lebih positif, menciptakan emosi positif dalam diri mereka, serta membuat mereka merespon segala sesuatu dengan lebih positif. Proses syukur yang dilatihkan kepada guru mencakup bersyukur dengan hati, lisan, dan perilaku. Ketiga hal tersebut merupakan satu kesatuan utuh yang harus dilakukan dalam bersyukur.

Dalam proses bersyukur dengan hati guru meyakini bahwa setiap situasi atau kejadian dalam hidup merupakan kehendak Tuhan sebagai tindakan altruistic Tuhan terhadap diri mereka. Proses ini membuat seseorang terdorong untuk terus memiliki persepsi yang positif dalam setiap situasi termasuk saat menghadapai berbagai sumber stres dalam 
bekerja sebagai guru di sekolah inklusi. Salah satu variabel yang mempengaruhi stres kerja adalah persepsi seseorang. Fitch-Martin (2015) menemukan bahwa bersyukur efektif menurunkan stres karena kebersyukuran memainkan peran penting terkait dengan bagaimana seseorang mempersepsikan suatu kejadian.

Dalam pelatihan kebersyukuran guru berlatih untuk menghilangkan keyakinan irasional (siswa seharusnya memiliki progres belajar yang cepat seperti yang mereka harapkan, siswa seharusnya tidak berperilaku mengganggu, dan sebagainya). Keyakinan irasional dapat dihilangkan karena dalam intervensi kebersyukuran terjadi perubahan dalam kognitif yang mempengaruhi keyakinan irasional guru (Tricarico, 2012). Dalam hal ini adalah guru belajar untuk mengembalikan segalanya kepada Tuhan karena perubahanperubahan (positif) yang diharapkan pada siswa dapat terjadi atas kehendak Tuhan bukan semata-mata karena guru saja. Guru berlatih untuk tidak hanya fokus pada harapan mereka tapi upaya yang dapat mereka lakukan, seperti memberikan layanan terbaik untuk siswa. Dengan demikian guru akan merasa lebih nyaman menjalani tugas mereka karena dilakukan semata-mata untuk ibadah kepada Tuhan. Tricarico (2012) menemukan bahwa, dengan menurunkan keyakinan irasional pada guru membuat guru lebih baik dalam menginterpretasi berbagai situasi yang dialami bersama siswa secara lebih rasional dan memberikan reaksi yang sesuai pada siswa.

Bersyukur juga membuat guru cenderung lebih fokus mencari hal positif di balik sumber stres (progres siswa yang lambat, perilaku mengganggu siswa, gaji yang minim) dalam pekerjaan mereka, dibandingkan memikirkan sumber stres itu sendiri. Hal ini berarti bersyukur menggerakkan guru untuk tetap berpikir positif dalam kondisi yang sulit sekalipun. Kebersyukuran mendorong seseorang untuk menginterpretasi kejadiankejadian secara lebih positif dan hal tersebut akan meminimalisir munculnya stres (Wood dkk, 2007).

Sebelum diberikan intervensi berupa pelatihan kebersyukuran, para guru umumnya merespon sumber stres dengan perasaan kecewa, marah, menggerutu, dan berbagai respon negatif lainnya. Bahkan hal tersebut berdampak pada kesehatan fisik mereka (merasa mudah lelah, pusing, asam lambung meningkat, dan lain-lain). Namun, setelah intervensi dan mengaplikasikan keterampilan bersyukur, para guru menjadi lebih positif dalam menilai berbagai sumber stres dan melibatkan Tuhan di dalam segala situasi. Hal ini berarti guru melakukan emotion-focused coping. Menurut Cahyono (2014), di dalam emotional focus coping terdapat positive reappraisal dimana individu mengubah pemikirannya secara positif dan mengandung nilai religious. Dampaknya, guru terhindar dari berbagai menifestasi negatif stres kerja, baik dalam hal emosi, fisik maupun perilaku. Kebersyukuran mendorong para guru untuk berpikir positif dan hal tersebut juga mempengaruhi munculnya emosi yang positif. McCullough, dkk (2002) menyebutkan bahwa seseorang yang bersyukur akan memiliki emosi positif. Hasil penelitian menunjukkan bahwa intervensi kebersyukuran membuat guru cenderung merasakan emosi positif, merasa lebih tenang dalam menghadapi masalah dan lebih sabar dalam bekerja maupun menghadapi siswa. Hasil temuan ini sejalan dengan temuan beberapa penelitian sebelumnya dimana bersyukur dapat memberikan dampak positif secara emosional (McCullough \& Emmons, 2002) dan mendorong seseorang memiliki gayacoping yang positif ketika menghadapi suatu masalah (Wood dkk, 2007). 
Pada penelitian ini juga ditemukan bahwa pelatihan kebersyukuran membuat guru lebih menghargai sekecil apapun pencapaian siswa. Perubahan sikap ini muncul karena dalam proses pelatihan kebersyukuran guru menyadari bahwa mereka tidak dapat mengubah siswa persis seperti yang mereka inginkan. Guru mengubah pemikiran mereka bahwa pencapaian siswa bukan hanya semata-mata karena guru sendiri melainkan juga ada campur tangan Tuhan. Dengan demikian, guru lebih menghargai sekecil apapun perubahan atau progress belajar siswa. Selain itu, guru juga terdorong untuk memberikan respon positif kepada siswa misalnya dengan tersenyum, mengucapkan terima kasih, memuji siswa, mendoakan siswa dan lain sebagainya. Berbagai tindakan tersebut berdampak pada tumbuhnya hubungan yang baik dan lebih dekat antara guru dengan siswa.

Kebersyukuran tidak hanya membawa dampak positif bagi guru maupun siswa saja. Kebersyukuran juga dapat memunculkan iklim positif di lingkungan kerja. Hasil penelitian ini menunjukkan bahwa guru-guru yang bersyukur cenderung lebih bersemangat untuk bekerja, tidak menunda pekerjaan mereka, lebih kompak,terdorong untuk saling membantu dan saling mendukung. Hal ini sejalan dengan temuan penelitian McCullough, dkk (2002) bahwa seseorang yang bersyukur lebih memiliki perasaan prososial, empatik, dan membantu orang lain. Pada penelitian ini juga ditemukan bahwa setelah mengikuti pelatihan kebersyukuran guru dapat menyelesaikan tugas-tugasnya tepat waktu. Hal ini dikarenakan guru-guru lebih terdorong menyelesaikan tugasnya. Kaplan, dkk (2013) menemukan bahwa kebersyukuran dapat meningkatkan keinginan berusaha.

Dampak lainnya dari intervensi kebersyukuran pada penelitian ini adalahmembaiknya kondisi fisik guru. Hal ini dapat terjadi karena pikiran dan emosi positif yang dirasakan dari bersyukur membuat guru lebih tenang dan lebih memperhatikan kesehatan fisik mereka, sehingga mereka terhindar dari berbagai manifestasi stres yang terwujud dalam gejala fisik seperti kelelahan, pusing, tekanan darah meningkat dan sebagainya. Menurut Tricarico (2012) apresiasi yang terdapat dalam pelatihan kebersyukuran membuat guru terhindar dari stres, kelelahan, burnout, dan penurunan pencapaian personal.Berdasarkan berbagai pemaparan hasil penelitian tersebut dapat disimpulkan bahwa, pelatihan kebersyukuran pada guru di skeolah inklusi dapat menurunkan stres kerja guru.

Terdapat kelemahan dalam penelitian ini yang dapat dijadikan perhatian bagi peneliti berikutnya. Berdasarkan informasi dari peserta pelatihan diketahui bahwa durasi pelatihan kebersyukuran dalam satu hari dianggap terlalu panjang sehingga memungkinkan terjadinya kejenuhan selama mengikuti pelatihan. Faktor kelelahan peserta pelatihan dimungkinkan dapat mempengaruhi hasil penelitian. Oleh sebab itu, perlu mempertimbangkan durasi waktu pelaksanaan pelatihan dalam satu kali pertemuan untuk menghindari terjadinya maturasi.

\section{SIMPULAN DAN IMPLIKASI}

Berdasarkan analisis data dan pembahasan yang dilakukan dalam penelitian ini maka dapat disimpulkan bahwa,pelatihan kebersyukuran dapat menurunkan stres kerja guru yang menjadi responden penelitian pada kelompok eksperimen.Sedangkan, pada kelompok kontrol yang tidak diberikan perlakuan berupa pelatihan kebersyukuran tidak terjadi penurunan stres kerja. Hal tersebut membuktikan bahwa intervensi berupa 
pelatihan kebersyukurandapat menurunkan stres kerja guru dan dapat dijadikan sebagai salah satu alternatif intervensi yang diberikan dalam menurunkan stres kerja guru di sekolah inkulusi.

Terdapat beberapa hal yang perlu disempurnakan agar pelaksanaan pelatihan kebersyukuran selanjutnya dapat memberikan hasil yang lebih optimal. Bagi responden penelitian, melihat bahwa hasil penelitian ini efektif untuk menurunkanstres kerja maka hendaknya responden penelitian terus mengaplikasikan keterampilan syukur dengan hati, lisan, dan perilaku dalam kehidupan sehari-hari agar terhindar dari stres kerja. Sementara bagi peneliti selanjutnya, pelatihan kebersyukuran hendaknya dilakukan lebih dari dua pertemuan agar setiap pertemuan memiliki durasi waktu yang lebih singkat. Penambahan jumlah pertemuan dengan durasi yang lebih singkat dilakukan sebagai upaya untuk menghindari kejenuhan pada peserta pelatihan.

\section{REFERENSI}

Al-Jauziyyah, I. Q. (2010). Sabar dan syukur: Menguak rahasia di balik keutamaan sabar dan syukur. Semarang: Pustaka Nuun.

Al-Munajjid, M. B. S. (2006). Silisilah amalan hati: Ikhlas, tawakkal, optimis, takut, bersyukur, ridha, sabar, introspeksi diri, tafakkur, mahabbah, taqwa, wara'. Bandung: Irsyad Baitus Salam.

Antoniou, A. S., Polychroni, F., \& Kotroni, C. (2009). Working with students with special educational needs in greece: teachers stressors and coping strategies. Internatioanl Journal of Special Education, 24, (1), 100 - 111.

Billingsley, B. S. \& Cross, L. H. (1992). Predictors of commitment, job satisfaction, and intent to stay in teaching: A comparison of general and special educators. The Journal of Special Education, 25, (4), 453-471.

Brackenreed, D. (2011). Inclusive education: identifying teachers' strategies for coping with perceived stressors in inclusive classrooms. Canadian Journal of Education Administration and Policy, 122, 1 - 37.

Cahyono, E.W. (2014). Pelatihan gratitude (Bersyukur) untuk penurunan stres kerja karyawan di PT "X”. Jurnal Ilmiah Mahasiwa Universitas Surabaya, 3, (1), 1 - 15.

Emmons, R. A., \& Crumpler, C. A. (2000). Gratitude as a human strength: Appraising the evidence. Journal of Social and Clinical Psychology, 19, (1), 56-69.

Emmons, R. A., \& McCullough, M. E. (2003). Counting blessings versus burdens: An experimental investigation of gratitude and subjective well-being in daily life. Journal of Personality and Social Psychology, 84, (2), 377-389.

Emmons, R.A. \& Stern, R. (2013). Gratitude as a psychotherapeutic intervention. Journal of Clinical Psychology, 69, (8), 846 - 855.

Fimian, M. J. (1988). Teacher stres inventory. USA: Clinical Psychology Publishing 
Fitch-Martin, A. (2015). Gratitude and health: a brief intervention to reduce undergraduate stress. Dissertation. Colorado: Colorado State University.

Kaplan, S., Bradley-Geist, J. C., Ahmad, A., Anderson, A., Hargrove, A. K., \& Lindsey, A. (2013). A Test of Two PositivePsychology Interventions to Increase Employee Well-Being. Journal of Business and Psychology, 29(3), 367-380. http://doi.org/10.1007/s10869-013-9319-4-9319-4

Kelso, T., French D., \& Fernandez, M. (2005). Stress and coping in primary caregivers of children with a disability: a qualitative study using the Lazarus and Folkman Process Model of Coping. Journal of Research in Special Educational Needs, 5(1), 3-10.

Lewis, B. (2006). Avoid burnout?!?! is it possible? Your guide to elementary educators. Diunduh dari http://k6educators.about.com/cs/helpforteachers/a/avoid burnout.htm.

Maslach, C., Schaufeli, W. B., \& Leiter, M. P. (2001). Job Burnout. Annual Reviews Psychology, 52, 397-422.

McCullough, M. E., Emmons, R. A., \& Tsang, J. A. (2002). The grateful disposition: A conceptual and empirical topography. Journal of Personality and Social Psychology, 82, (1), 112-127.

McCullough, M. E., Tsang, J. -A., \& Emmons, R. A. (2004). Gratitude in intermediate affective terrain: Links of grateful moods to individual differences and daily emotional experience. Journal of Personality and Social Psychology, 86, (2), 295309.

Puspitasari, D. A. \& Handayani, M.M. (2014). Hubungan tingkat self-efficacy guru dengan tingkat burnout pada guru sekolah inklusi di Surabaya. Jurnal Psikologi Pendidikan dan Perkembangan, 3, (1), 59 - 68.

Shadish, W. R., Cook, T. D., \& Campbell, D. T. (2002). Experimental and quasiexperimental design for generalized causal inference. USA: Houghton Mifflin Company.

Tricarico, H. L. (2012). The impact of a brief gratitude intervention for teachers. Disertation. New York: UMI Disertation Publishing

Widhiarso, W. (2010). Aplikasi Anava campuran untuk desain eksperimen Pre-Post Test Design.Yogyakarta: Fakultas Psikologi Universitas Gadjah Mada.

Wimbarti, S. (2016). Deteksi dini dan manajemen kelainan balita di Sekolah dan Keluarga. Seminar dan Workshop Anak Berkebutuhan Khusus. Fakultas Psikologi Universitas Gadjah Mada, Yogyakarta. 
Wood, A. M., Joseph, S., \& Linley, P. A. (2007). Coping style as a psychological resource of grateful people. Journal of Social and Clinical Psychology, 26, (9), $1108-1125$. 